\title{
Women, Popular Science and Recreation: The First 25 Years of the South Australian Field Naturalists
}

Sharyn Clarke

University of Adelaide, Adelaide, SA

\begin{abstract}
This article is an examination of women's role in the South Australian Field Naturalists in its first 25 years, from 1883-1908. Historical attention has tended to focus on inspiring female naturalists or illustrators. However, science also had a popular following amongst women. An examination of women's roles provides insight into a number of historical issues. Understanding of gender relations and power in amateur organisations at this time is enhanced. Amateur female participation in botany was still vigorous and women who collected and/or illustrated were significant contributors to the organisation. By the mid-century, women with science degrees would also seek to find their place. Yet, there was tension in regard to women's roles. This was an organisation run partly for the amateur, by the still patriarchal Royal Society, with the strong scientific credentials of the male leaders a barrier for female scientists. Finally, and significantly, for many women their concern was predominantly recreational, with participation in field naturalism an overlooked organised leisure activity in South Australia.
\end{abstract}

The settlement of Australia took place in an era characterised by scientific endeavour, with interest in the natural world a popular pursuit. By the nineteenth century, field naturalism had become a global phenomenon and by the 1880s in Australia amateur organisations were emerging due to a general interest in science, the rise of an educated middle class and increasing hours for recreation, with field naturalist clubs also opening 
up avenues for political protest. ${ }^{1}$ For women, an emphasis on healthy outdoor activity, and the association of their gender with botany were further societal forces facilitating their involvement. This article is an examination of women's roles and contribution to one particular organisation, the South Australian Field Naturalists, from its inception in 1883 until around 1908, when it celebrated its 25th anniversary.

There has been a wealth of studies on individual female naturalists in the Western world in the nineteenth century and, in Australia, historical attention has similarly concentrated on individuals who left diaries of their exploits: collectors such as Georgiana Molloy, or painters such as Ellis Rowan. However, there has been limited examination of women in Australian field naturalist organisations. ${ }^{2}$ Certainly, the available historical records focus less on the pioneering individual, with minutes from meetings and records of excursions the main sources. Existing historical scholarship of women in the South Australian Field Naturalists is confined to the collector, Jessie Hussey, and artist, Rosa Fiveash. ${ }^{3}$

Examining women's roles in the Field Naturalists provides insight into the position of women in popular science in what was a transitional period, both in regard to science and its increasing professionalisation, and, in particular, to women's position within it. Studies of Western women in science in the nineteenth century have tended to emphasise institutional bias and the existence of strongly gendered spheres. However, as Jane Carey has observed in her analysis covering 1885-1940, the perception of science as inhospitable to women is not necessarily upheld in Australia, with women having a greater presence than is often assumed, and with their participation quickly established at the University of Melbourne. ${ }^{4}$ Similarly, at the University of Adelaide, by 1900 female graduates in science outnumbered any other discipline with their entry encouraged by male mentors at the State's Advanced School for Girls. ${ }^{5}$ Other studies have

1 Drew Hutton and Libby Connors, A History of the Environment Movement in Australia (Cambridge: Cambridge University Press, 1999), 40-41.

2 For an exception, see Sheila Houghton, “If It Is Not Against the Rules”: Women in the Field Naturalist Club of Victoria 1880-1980', Victorian Naturalist, 122, no. 6 (2005): 290-306.

3 See Hutton and Connors, History of the Environment Movement, 30; Darrell Kraehenbuehl, 'Jessie Louisa Hussey', in People and Plants in Australia, ed. D. J. Carr and S. M. Carr (Sydney: Academic Press, 1981), 338-98. The most recent work on Fiveash is in Penny Olsen, Collecting Ladies: Ferdinand von Mueller and Women Botanical Artists (Canberra: National Library of Australia, 2013).

4 Jane Carey, 'No Place for a Woman? Intersections of Class, Modernity and Colonialism in the Gendering of Australian Science', 1885-1940', Lilith: A Feminist History Journal, no. 10 (2001): 154.

5 Alison Mackinnon, The New Woman: Adelaide's Early Graduates (Adelaide: Wakefield Press, 1986), 27,31 . 
suggested, however, that while there were no formal barriers for women there were societal factors and expectations that restricted women's options once they achieved their degree. ${ }^{6}$ Claire Hooker has positioned women as 'popularisers' and 'illustrators' during this time, rather than authorities, but suggests that women perceived the culture of natural history as a space shared with men, with many receiving respect and recognition from male peers. ${ }^{7}$

This study illuminates the influence of gender relations and power in this amateur organisation and upholds women's participation in popular science. The organisation emerged at a time when women were becoming more involved in public activities and their rights were being recognised, with South Australian women achieving full suffrage in 1894. While in 1908 W. H. Selway noted in his chairman's address at the 25th anniversary that the 10 foundation members who survived were all men, within the organisation women played a significant role, confirming that the culture of natural history was in some ways shared. Women collected, illustrated, assisted, exhibited, instructed and organised functions. ${ }^{8}$ They were much more active, scientifically and culturally, than official membership lists suggest. However, there was tension in regard to women's status and authority. This was an organisation run partly for the amateur by the still patriarchal Royal Society where women could only be associate or corresponding members. The hierarchy in the Field Naturalists' structure meant that male scientists were paramount and women faced obstacles to equal representation and authority. The address and papers at meetings were typically given by the authoritative male voice of a respected scientist, but such times when women did read papers mark a shift where the female voice began to assert some influence into the arena of professional science. Amateur female participation in botany was vigorous in the organisation, with women who collected and/or illustrated strongly represented, and towards the end of the century women with science degrees would also seek to find their place. For many women their concern was predominantly recreational, with the organisation providing both intellectual and physical recreational activity.

6 Farley Kelly, 'Learning and Teaching Science', in On the Edge of Discovery, ed. Farley Kelly (Melbourne: Text Publishing, 1993), 40.

7 Claire Hooker, Irresistible Forces: Australian Women in Science (Melbourne: Melbourne University Press, 2004), 12.

8 Advertiser, 19 November 1908, 8. 


\section{The Field Naturalists: The General Female Membership}

The South Australian Field Naturalists began as an initiative of the Royal Society formed by geologist and botanist Professor Ralph Tate, chair of Natural Science at the University of Adelaide, in 1880. Tate and other 'gentlemen' who had been involved with clubs in England and Ireland were behind the organisation's establishment, which was originally suggested by Tate at a Royal Society meeting in 1881 and finally endorsed in 1883. ${ }^{9}$ This link with the Royal Society differs from similar organisations in other colonies, such as Victoria, where the Field Naturalists were formed independently in $1880 .{ }^{10}$ Female membership was assumed and welcomed and its recreational intent made explicit. Lectures were to be 'both entertaining and instructive' and there would be at least eight Field Meetings per year. The aim was: 'the practical study of natural history, as an intellectual recreation, by means of excursions and by evening meetings. ${ }^{11}$ At Tate's opening lecture, 'a statement of the Lecturer that Ladies were especially welcome to become members was greeted with "loud applause" and short promotional advertisements in local newspapers emphasised women's inclusion. ${ }^{12}$ Female members were primarily middle class, often single, and had to be proposed by existing members, leading to a close network of friends and family. ${ }^{13}$ Married women in Adelaide often went on excursions with their husbands, and were sometimes the wives of scientists, while a few married rural women were collectors.

Science societies were complex organisations; they had cultural capital, but they also had to carefully balance recreational and scholarly aims. ${ }^{14}$ Field naturalism was generally understood in society as a healthy recreational option for women. While domesticity was encouraged for middle-class women in the nineteenth century, the parallel ideology that endorsed

9 Chronicle, 6 August 1881, 9; W. H. Selway, 'Our Beginnings', South Australian Naturalist, 1, no. 1 (1919): 3.

10 Gary Presland, Understanding Our Natural World: The Field Naturalists' Club of Victoria 1880 2015 (Blackburn: Field Naturalists Club of Victoria, 2016), 2-6.

11 'Appendix: Transactions of the Field Naturalists' Section of the Royal Society of South Australia', Transactions and Proceedings and Report of the Royal Society of South Australia, 7 (1883-84): 112-13; Selway, 'Our Beginnings', 3.

12 W. H. Selway, 'Brief History of the Field Naturalists' Section', South Australian Naturalist, 25, no. 3 (1934): 67; Adelaide Observer, 15 October 1887, 27.

13 'Transactions of the Field Naturalists (1883-84)', 113.

14 Kerrie Kennedy, 'Science Culture in the Nineteenth Century: Women and the Botanical Society of Canada', Resources for Feminist Research, 33, no. 3-4 (2010): 54. 
healthy outdoor activity has at times been underplayed. ${ }^{15}$ Moreover, discourses of the 'New Woman' were proliferating in the 1890s, with outdoor activity seen as desirable for women's mental and physical health. The Observer summarised in 1896: 'the sensible new woman can ride, and swim, and run, and row, and her nobly developed limbs are clad in garments of becoming looseness'. ${ }^{16}$

Botany had also been established as part of a girl's education for those from the middle and upper ranks. From the late eighteenth century, the delicacy and beauty of plants were viewed as aesthetically concordant with the feminine, while examination of the natural world also taught important religious and moral lessons. While botany was thought to reinforce ideas about separate spheres and appropriate behaviour, a new emphasis on reason and women's rights also assisted women's passage into botanical work. ${ }^{17}$ Educationalists in nineteenth-century Australia recommended that girls study science, given their close association with the natural world, and it was popular in many all-girls' schools. ${ }^{18}$

The Field Naturalists were formed before the 1890s' ornithological and bushwalking movements, with the desireforwomen to interact with thegreat outdoors expanding during the 25 years of this study. Formal recreational pastimes and organisations were increasing, particularly amongst the middle class, with leisure hours and transportation systems assisting travel to areas around Adelaide, and with all of these forces contributing to the Field Naturalists' establishment. The recreational aspect is attested to by the much larger attendance at outings than meetings. Evening meetings were initially meant to be for reading papers mirroring the Royal Society's procedural framework, but such serious aims were immediately subverted as more members came when exhibitions were held and often divergent activities were instigated by women. ${ }^{19}$ By 1886 , attractions also included 'gossip meetings' and 'conversaziones', held annually since 1887, which epitomised the intellectual recreational aspect, with women being keen

15 Glenda Riley, 'Victorian Ladies Outdoors: Women in the Early Western Conservation Movement', Southern California Quarterly (Spring 2001): 60.

16 Alison MacKinnon, The New Woman: Adelaide's Early Graduates (Adelaide: Wakefield Press, 1986), 15.

17 Anne Shteir, Cultivating Women, Cultivating Science: Flora's Daughters and Botany in England 1760 to 1860 (London: John Hopkins University Press, 1996), 36, 173.

18 Sara Maroske, 'The Whole Great Continent as a Present', in On the Edge of Discovery, ed. Kelly, 24.

19 There were complaints about the poor attendance at evening meetings in 1885 , leading to diversification in the offerings. 'Annual Meeting', 13 October 1885, Proceedings of the Field Naturalists' Section of the Royal Society of South Australia for 1884-1885 (Adelaide: Royal Society of South Australia, 1886), 35 . 
exhibitors of both paintings and specimens, rivalling men's contributions, despite the latter often being from prominent scientists. ${ }^{20}$ Their diverse exhibits, often from their travels, included reptiles, bats and insects, with some gifted to the Adelaide Museum. ${ }^{21}$

The Field Naturalists also had serious scientific aims, with its Royal Society leadership in many ways a strength. However, the emphasis on leisure was highlighted in frustration that members may have 'lost sight of the real object of the evening meetings', as in a pointedly titled 1887 paper, 'a scheme for the more systematic study of science on excursions'.$^{22}$ Excursion notes from 1907 suggest continued division in a reference to 'non-scientific' members. ${ }^{23}$ Certainly, there were competing interests, but the recreational aspect was encouraged, with Tate clarifying that it was not intended to exclude those who sought solely companionship and agreeable change'. ${ }^{24}$

Overall, there are many reasons to see the Field Naturalists as an organisation that contributed to leisure in South Australia, although they have tended to be classified as purely scientific. For example, in Time for Play: Recreation and Moral Issues in Colonial South Australia (2015), Denis Molyneux overlooks field naturalism or ornithology, despite covering other educational recreational groups such as Workers' Institutes. The number of participants in the Field Naturalists was not large, but they were very well-known and their activities regularly published in Adelaide's newspapers. While clothing and competition are cited by Molyneux as restrictions on female leisure, women's clothing did not appear to be an impediment, nor was the activity competitive. ${ }^{25}$ Other studies have suggested that, as women began to join men in outdoor pursuits, demand for garments led to new products; the activities undertaken by the new woman thus challenged traditional restrictive female fashion. ${ }^{26}$

20 'Annual Meeting', 18 October 1887, Proceedings of the Field Naturalists' Section of the Royal Society of South Australia for 1886-1887 (Adelaide: Royal Society of South Australia, 1888), 14; Register, 21 November 1898, 7.

21 Observer, 20 November 1897, 16.

22 'Annual Meeting', 13 October 1885, Proceedings of the Field Naturalists' for 1884-1885, 35; 'Fourth Annual Report', Proceedings of the Field Naturalists' Section of the Royal Society of South Australia for 1886-1887 (Adelaide: Royal Society of South Australia, 1888), 13.

23 Register, 27 February 1907, 5.

24 'Transactions of the Field Naturalists (1883-84)', 112.

25 Denis Molyneux, Time for Play: Recreation and Moral Issues in Colonial South Australia (Adelaide: Wakefield Press, 2015), 5.

26 Arlesa J. Shephard, 'Waterproof Dress: Patents as Evidence of Design and Function from 1880 through 1895', Clothing and Textiles Research Journal, 30, no. 3 (2012): 184; Carol Bacchi, 'The "Woman Question" in South Australia', in The Flinders History of South Australia, ed. Eric Richards (Adelaide: Wakefield Press, 1986), 410. 
Very detailed notes were taken on excursions, even of the activities themselves, which demonstrate that many women faced the challenges enthusiastically. The conditions were sometimes difficult with participants encountering dense scrub or steep slopes and it was noted that women's headwear suffered when scrambling through overgrown tracks. Nevertheless, women generally tramped across the terrain with men. Records from an 1899 excursion describe 'the ladies for the most part keeping pace with the men and surmounting all difficulties in spite of great odds. ${ }^{27}$ Women were also not adverse to occasional risks when searching for unusual botanical specimens and are recorded as participating in strenuous physical work such as rowing. ${ }^{28}$ Similarly, in 1900 the 'ladies' were advised not to attempt a steep descent to the River Torrens, but many choose to do so regardless. ${ }^{29}$

The first report of the Field Naturalists shows 11 women, two married, out of 165 listed members, and official numbers of women would continue to be low during this time, a trend also observed in the Victorian Field Naturalists. ${ }^{30}$ However, many more attended excursions and exhibits, with friends happily accepted on such occasions: reports from 1886 show 16 outings, doubling initial expectations. ${ }^{31}$ In $1887-88$ it was noted that of the 21 new members, nine were women. By 1890, the proportion of women had increased, although they still only numbered 15 out of $108 .{ }^{32}$ However, an excursion in 1909 that listed participants and their marital status is telling. Overall women far outweighed men, a fact acknowledged by the author: 'the fairer sex predominated'. There were 27 women and 18 men with 19 single women and eight married; of the latter, six attended with their husbands, two without. ${ }^{33}$

27 Advertiser, 22 November 1899, 7.

28 Express and Telegraph, 21 September 1903, 4; Register, 9 March 1885, 7; Advertiser, 22 November $1899,7$.

29 Observer, 17 November 1900, 32.

30 'Transactions of the Field Naturalists (1883-84)'; 'List of Members', 132-5; Maroske, 'Whole Great Continent', 21-22.

31 Proceedings of the Field Naturalists' Section of the Royal Society for, 1884-85, 'Appendix', 6; Proceedings of the Field Naturalists' Section of the Royal Society for 1885-6, 'Annual Meeting', 19 October 1886, 291. 32 Proceedings of the Field Naturalists' Section of the Royal Society, for 1887-88 (Adelaide: Royal Society of South Australia, 1889), 247; Proceedings of the Field Naturalists' Section of the Royal Society for 1889-90, 'List of Members' (Adelaide: Royal Society of South Australia, 1891), 38-40.

33 Observer, 4 December 1909, 6. 
Many women in the Field Naturalists embraced the recreational aspect and took the initiative. Young women pushed the society in a direction where female middle-class accomplishments were frequently displayed, not just in illustration but also in music, as in a meeting held 'at the invitation' of two sisters featuring female members performing on the piano and reciting poetry. Music was also a feature of the annual picnic and conversaziones and longer trips included musical and dramatic performances. ${ }^{34}$ Field Naturalists' interests also extended outside official events, as in a native flower afternoon tea with native flora a decorative motif. ${ }^{35}$

Women in the Field Naturalists engaged in collecting and collating South Australian nature in a way that fundamentally differed with Indigenous use and understanding of the land. However, we do see some interest by young white women in the material culture of Aboriginal peoples, particularly Indigenous women, when anthropological and scientific attention turned to Central Australia in the late 1890s. Ellis Rowan, for instance, notably engaged with Indigenous people when gathering specimens and information related to botany and ethnobotany in remote regions such as Northern Queensland. ${ }^{36}$ However, women in the Field Naturalists, in a twist on the usual scenario of women collecting for men, appear to have taken advantage of the travel experiences of their fathers. In 1901, a Miss L. A. Tilly explained her exhibits of Aboriginal implements, and between 1897-88 Lottie Benda exhibited plants and items collected by her father, showing a particular interest in Indigenous women's adornments. ${ }^{37}$ By 1900 she was exhibiting shells from the Northern Territory coast and was on the Field Naturalists' committee. ${ }^{38}$ Miss F. E. R. Hunt, a regular contributor between 1893 and 1904, displayed a range of Aboriginal artefacts, presumably also collected by her father who was involved in government engineering. These included spears, 'shoes' and seed pods from Central Australia and an extensive collection of Aboriginal foods, including roots and bulbs, from the Cooper Creek region with Hunt explaining cooking techniques and the use of different items. ${ }^{39}$

34 Register, 23 December 1901, 8; Advertiser, 11 December 1905, 8; Register, 17 November 1904, 3.

35 Chronicle, 12 November 1904, 30.

36 Philip A. Clarke, Aboriginal Plant Collectors: Botanists and Australian Aboriginal People in the Nineteenth Century (Kenthurst: Rosenburg Publishing, 2008), 112.

37 Register, 23 December 1901, 8; Register, 19 April 1899, 3.

38 Observer, 13 April 1895, 13; Observer, 23 October 1897, 15; Register, 21 November 1898, 7; Register, 19 April 1899, 3; Register, 18 July 1900, 3; Advertiser, 19 September 1900, 9.

39 Evening Journal, 20 July 1898, 3; Advertiser, 21 September 1898, 7; Advertiser, 19 November 1898, 5; Register, 24 August 1899, 6; Advertiser, 25 April 1900, 9. 
While these women showed an interest in Aboriginal women's material culture, it generally appears to be from a natural science perspective and, ultimately, can be seen as part of the wider appropriation and cataloguing of Aboriginal artefacts during this time.

Often a woman's family's association with science had a significant impact on her own involvement. ${ }^{40}$ Chrissie Selway was positioned as her brother W. H. Selway's 'right-hand supporter in assisting the society in a multitude of ways. ${ }^{41}$ Eliza Mellor and her husband, John Mellor, an ornithologist, were avid contributors in a passion that involved their family and much of their lives. Both Chrissie and Eliza were more than just supporters though. Eliza, who was in charge of the family garden at the Reedbeds, saw it as a bird sanctuary and was an 'ardent' naturalist, conservationist and talented artist who would be an active member of the Field Naturalists for 35 years. ${ }^{42}$ Some married women, such as Mrs S. L. Schourup, stand out for their individual efforts. Schourup was a member of the committee from 1896 to 1904 and had regularly exhibited since 1892, being particularly interested in insects. ${ }^{43}$ In 1899 she delivered a paper based on her 12 years living on the South Island of New Zealand. ${ }^{44}$

The Field Naturalists enabled women's access to a variety of locations around Adelaide in areas rich in scientific interest and provided education from distinguished scientists. Excursion notes, while a thorough botanical record, also provide commentary on gender. Men were the official experts with senior scientists explaining items of interest and Tate regularly heading parties in the early years. Outings were invariably accompanied by a meal at a local house or hotel, highlighting the recreational aspect, and women frequently placed in the role of hostesses at afternoon tea, often followed by a garden tour. However, gendered associations of Victorian femininity with certain botanical types were often contravened. Women were not necessarily attracted to the beautiful, as might have been expected of them, but often to the obscure, such as unusual seeds, ants and reptiles. ${ }^{45}$

40 Leonie Norton, Women of Flowers: Botanical Art in Australian from the 1830s to the 1960s (Canberra: National Library Association 2009), 6.

41 Observer, 4 December 1909, 6.

42 Penny Paton, 'John White Mellor (1868-1931) Part 1,' SAOA Historical Series, no. 64 (2018):

2; Register, 8 October 1919, 7.

43 Register, 20 November 1901, 5.

44 Register, 21 June 1899, 2.

45 Register, 1 December 1885, 7; Advertiser, 19 August 1907, 6. 
A possible snake sighting in 1894 shows a visiting English field naturalist asserting her expert opinion: 'the lady, who has considerable experience of both kinds of reptiles, remained firm in her conviction'. ${ }^{46}$

Women were commonly perceived as interested in the aesthetically pleasing aspects of flora and fauna, though this was filtered through the eyes of the male secretary, Lock, who tended himself towards the visual and romantic. ${ }^{47}$ As women increased their presence in the workforce in the early twentieth century the Field Naturalists began to avail themselves of their secretarial skills. In 1906 Miss Hocking was on the committee, as minutes secretary, and she would serve a long apprenticeship before moving on to assistant secretary in $1913 .{ }^{48}$ The 1880 s and 1890 s saw a marked increase in women's participation in organisations. Yet, despite this, men were placed in positions requiring expertise. A quotation from 1896, from the female initiator of one such association, gives some insight: 'no committee that consists of ladies could get on thoroughly well without a gentlemen as Secretary'. ${ }^{49}$ Yet, even in this context, the Field Naturalists were extreme in their male leadership. During the period between 1883-1908, the position of chair, president, vice-president, secretary and treasurer were all occupied by men. It would not be until 1933, 50 years after its inception, that the Field Naturalists appointed their first female secretary. ${ }^{50}$

A number of sub-committees were to emerge from the Field Naturalists, the most significant one being the Fauna and Flora Protection Committee in 1888, but women were also absent from this. Delineated gender roles were commonly followed in the organisation. Male exclusivity in the Protection Committee was not a rule, but based on authority, perhaps seen to be needed for effective campaigning. In South Australia, as in other parts of Australia, women were more prominent in fauna protection. ${ }^{51}$ Such organisations were often female-initiated and female-focused, with Eliza Mellor helping to establish the South Australian Branch of the SPCA. It would not be until 1920 that the first women would appear in the Protection Committee, with Benda, now in her 60 s, one of the first elected. ${ }^{52}$

46 Advertiser, 15 May 1894, 6.

47 Register, 21 November 1898, 7; Register, Wednesday 21 May 1902, 6.

48 Advertiser, Wednesday 19 September 1906, 8; Advertiser, 21 December 1900, 3; Register, 24 September 1913, 15.

49 Helen Jones, In Her Own Name: Women in South Australian History (Adelaide: Wakefield Press, 1986), 40-41.

50 News, 30 June 1933, 8.

51 See Hutton and Connors, History of the Environment Movement, 40-41.

52 Paton, 'John White Mellor', 2; Register, 28 September 1920, 6. 


\section{Illustrators}

In 1907 the esteemed scientist J. H. Maiden addressed the Australasian Association for the Advancement of Science (AAAS) in Adelaide with his survey of 'A Century of Botanical Endeavour in South Australia'. That this endeavour was undertaken by men was assumed: the aim was 'to learn of the men to whom we are indebted for the foundational knowledge that we build on today'. However, in a tiny entry, without any biographical notes, appears a sole woman, 'De Mole, Miss F.E., author of "Wild Flowers of South Australia", Twenty plates, 1861'. ${ }^{53}$ Botanical illustration was one area where women could make an, albeit small, mark. During the eighteenth century, botanical illustration became used for both descriptive and systematic science and, by the nineteenth, there was a 'rich and rewarding alliance between science and art'. ${ }^{54}$ Anne Shteir has charted the strong development of women's botanical illustration and writing in England in the mid-nineteenth century. ${ }^{55}$ Similarly, in South Australia, some women's botanical paintings and books were published from quite early on, highlighting that the colony's flora was something of curiosity, not just to settlers but also to those in England. ${ }^{56}$ At the time of the Field Naturalists' inception, artistic accomplishment was seen as part of the repertoire of a refined young middle-class woman and, more broadly, the cultivation of art, like science, promoted as significant for the colony's progression. ${ }^{57}$

It is thus no surprise that many of the dedicated women in the Field Naturalists found illustrating a rewarding use of their skills, with their scientific representations of plants often an adjunct to findings and explanations. Elizabeth B. Keeney has suggested that botany allowed women to subtly transgress acceptable behavioural standards whilst facilitating participation by both genders, thus challenging the ideology of separate spheres. ${ }^{58}$ It is in the area of illustration that the greatest collaboration took place with women illustrators supporting both men

53 J. H. Maiden, A Century of Botanical Endeavour in South Australia (Adelaide: Australasian Association for the Advancement of Science, 1907), 4, 7.

54 Ann Moyal, A Bright and Savage Land: Scientists in Colonial Australia (Sydney: Collins, 1986), 9.

55 Shteir, Cultivating Women, 197-213.

56 D. J. Carr, 'The Contribution of Women to Australian Botany', in People and Plants in Australia, ed. Carr and Carr, 325.

57 Chronicle, 27 January 1883, 4.

58 Elizabeth B. Keeney, The Botanizers (Chapel Hill: The University of North Carolina Press, 1992), 72 . 
and, even more frequently, other women. ${ }^{59}$ Exotic species, particularly orchids, were a popular subject, with their rarity and difficulty in propagation only furthering their appeal. ${ }^{60}$ In scientific illustration the aesthetic was intertwined with the educational, with art technically focused and emphasising realism. Women's exhibits and undertakings at times moved their work into the public forum. Lottie Benda, reported to be well-known for her 'life-like' drawings, had one of her paintings gifted to the Princess of Wales. ${ }^{61}$ Chrissie Selway, perhaps frustrated with her role as assistant, launched an ambitious project of painting all the orchids in Tate's Orchids of South Australia, in oil on porcelain, along with a scientific key. The links developed through the Field Naturalists are suggested in Selway's use of her network throughout the colony to obtain specimens. The final porcelain products, while seen as being of both 'artistic and scientific merit', were later gifted by Selway to the Adelaide Art Gallery. ${ }^{62}$ By doing so it suggests not only her sense of civic duty but the significance she attributed to her work.

The Field Naturalists provided a place for amateur artists to display their art and contribute to scientific knowledge, but one of the first professional female South Australian illustrators, Rosa Fiveash, was also a member. She was one of the few official female members in its formative years and often exhibited paintings. Her work always drew admiration, and later, in the 1920 s, she was something of a drawcard at wildflower exhibitions. ${ }^{63}$ Professionalism in art was often propelled by important contacts, although a few women did so from financial necessity, and it is probable that Fiveash also benefited from the Field Naturalists' network. ${ }^{64}$ Fiveash was the first professional teacher of china painting in South Australia between 1894-96, where she encouraged the incorporation of Australian motifs in her students' work, and here we again witness the movement of ideas and techniques from the scientific to the artistic world. Even in 1929 it was noted that art students continued to carry on traditions established

59 For example, E. F. Haycraft was aided in her talk by Benda's diagrams and in 1901 Chrissie Selway assisted with an orchid painting. Advertiser, 24 August 1900; Register, 23 December 1901, 8. 60 See, for example, Observer, Saturday 20 November 1897, 16; Register, 21 November 1894, 3; Register, 23 December 1901, 8; Advertiser, 20 April 1892, 7.

61 Register, 17 February 1905, 3.

62 Chronicle, 6 November 1926, 47; Australian Women's Mirror, 10 January 1928, 20; Register,

19 November $1927,5$.

63 Advertiser, 19 October 1887, 5; News, 4 August 1937, 9; Register, 9 October 1920, 10.

64 Norton, Women of Flowers, 2. 
by Rowan and Fiveash. ${ }^{65}$ While Fiveash rarely went on Field Naturalist excursions, a noteworthy exception is her attendance with Ellis Rowan in $1906 .{ }^{66}$

For both Selway and Fiveash their contribution was recognised as spanning the arenas of art and science. In Selway's short obituary in 1926, she was said to be well known in both, with her membership of the Field Naturalists, the AAAS and her dedication to her church acknowledged. In 1937, with Fiveash now 83, her active membership of the Field Naturalists was recognised, as was her devotion to nature studies: 'her life work, her hobby, and her delight'. ${ }^{67}$

\section{The 'Serious Collector'}

Given women's late entry into universities in the nineteenth century, examination of female naturalists in the Victorian age has often focused on amateurs able to claim a place in the scientific world. Moyal presents two groups: serious botanical collectors and botanical 'excursionists' and illustrators. ${ }^{68}$ Ferdinand Mueller exploited the acceptance of women's interest in botany to enlarge his pool of collectors and also used some female Aboriginal collectors. ${ }^{69}$ Within the South Australian Field Naturalists there was one 'serious collector' who had significant involvement: Jessie Hussey; while also of note is Mrs Annie F. Richards who is recorded as sending dried and pressed plants to the Field Naturalists in 1887, 1890 and $1893 .{ }^{70}$ Richards, the daughter of a chemist, was married to a police trooper posted to remote regions of South Australia. ${ }^{71}$ However, for

65 Avis Carol Smith, 'Changing Fortunes: The History of China Painting in South Australia' (PhD thesis, University of Adelaide, 2008), 18; Advertiser, 23 August 1929, 19.

66 Advertiser, 16 October 1906, 10.

67 Chronicle, 6 November 1926, 47; News, 4 April 1932, 8; News, 4 August 1937, 9.

68 Ann Moyal, 'Collectors and Illustrators: Women Botanists of the Nineteenth Century', in People and Plants in Australia, ed. Carr and Carr, 334.

69 Sara Maroske, “"A Taste for Botanic Science”: Ferdinand Mueller's Female Collectors and the History of Australian Botany,' Muelleria: An Australian Journal of Botany, 32 (2014): 73, 75.

70 Advertiser, 19 October 1887, 5; Observer, 25 October 1890, 32; Observer, 26 August 1893, 16.

71 Sara Maroske and Alison Vaughan, 'Ferdinand Mueller's Female Plant Collectors: A Biographical Register', Muelleria, 32 (2014): 130. 
Richards it appears that the Field Naturalists' urban emphasis resulted in negligible benefits and she had more continuous involvement with the Royal Society. ${ }^{72}$

Jessie Hussey was an algologist, a notable subset of female collectors. In five years, between 1893 to 1899 , she sent over 2,000 species of plants to Mueller in Melbourne for identification. Collecting engaged one in the variety and beauty of Australian flora, sometimes leading to new attachments and perceptions; at other times, as with Hussey, her already strong connections and interests in the natural world were furthered by the vocation. ${ }^{73}$ While female collectors were constrained in their geographic localities due to their limited access to transport, for some collecting was seen as branching away from the private sphere. ${ }^{74}$ Hussey's search for specimens entailed scrambling alone along the beaches of the Fleurieu Peninsula and venturing to scrubland away from Victor Harbour, with one of her favourite spots being the waterfalls near Port Elliot. ${ }^{75}$

Women's capacity to make a mark in science was often dependant on their ability to evade domestic commitments. ${ }^{76}$ Hussey's father was politically active in regard to issues such as democratic reform and women's rights, and her mother was well known for her philanthropic work in the community and her advocacy of women's education. ${ }^{77}$ Hussey had strong links with the Field Naturalists, was acknowledged as a valued member, and her significant personal collection at times visited by the organisation. She also brought other family members along to meetings, as in 1898 when she requested algae samples for an international collection. ${ }^{78}$ There are many records of her having sent specimens, often of rare or varietal forms, and her position of authority was reinforced by a paper delivered to the Field Naturalists in 1897 on South Australian algae (which also reversed typical gender roles, with her brother acting as assistant). Hussey pointedly assumed the role of a populariser, although her aims were sophisticated, with her professed desire being to establish scientific

72 There were few female corresponding members, see Selway, 'Brief History', 73; Richards had been a member of the Royal Society since 1880. 'List of Fellows, Members, \&c.', Transactions and Proceedings and Report of the Royal Society of South Australia, 3 (1879-80): iv.

73 Hooker, Irresistible Forces, 14.

74 Maroske, “'A Taste for Botanic Science”, 79; Hooker, Irresistible Forces, 14.

75 Chronicle, 14 November 1896, 18.

76 Maroske, 'Whole Great Continent', 27.

77 Register, 14 August 1891, 6; Observer, 30 May 1914, 41. See also SLSA, D 7739(L), Letters written by Catherine Hussey, c. 1843-52.

78 Express and Telegraph, 17 August 1898, 3. 
networks, communication and authorities in algology and to further scientific knowledge: 'our coast was very rich in Algae, and science should have the benefit of it'. Hussey, like Richards, contributed a paper to the Royal Society in 1897, entitled 'Land Flora, Port Elliott', suggesting acceptance by both in the larger realm, and she was also acknowledged officially in a number of new species. ${ }^{79}$

Jane Carey's conclusion that women in science often understood that they were in a position of privilege, despite systemic bias, is also applicable in Hussey's case. While Carey surveyed women graduating between 1930 and 1955, her insights are transferable: 'compared to most women, and indeed men, of their time, they were extremely fortunate, a fact which some were clearly aware of ${ }^{80}$ Carey observed that many of these women came from privileged families who had supportive attitudes towards women's education and, moreover, that tertiary studies at the time favoured women of a particular race, class and educational background. ${ }^{81}$ Despite the difference in historical periods, there are obvious parallels with Hussey, with her supportive parents and educated middle-class background, and, indeed, such parallels are applicable generally to women in the Field Naturalists. However, Hussey was notable in the level of equality which she assumed, and this could owe much to the political ideals apparent in her family. While Hussey was cognisant of the disparity in her relationship with Mueller, she also gave her opinions and observations freely and, in contrast with most of Mueller's collectors, formed her own relationships with overseas botanists. ${ }^{82}$

At the age of 27, Hussey had a serious illness leaving her hearing impaired. Further, as the sole daughter, she was required to care for her parents. Hussey's obituary emphasises her 'patient submissiveness' and dutiful disposition, both towards the poor and the sick and her parents, 'never allowing her love of Nature from a scientific view to interfere with her filial affections and duties', demonstrating that the stereotype of women in science as amateurs working for the advancement of society

79 Register, 16 June 1897, 3; Evening Journal, 7 April 1897, 3; 'List of Fellows, Members, \&c.', Transactions of the Royal Society of South Australia, 3 (1879-80): iv; Maroske, 'Whole Great Continent', 28; Kraehenbuhl, 'Jessie Louisa Hussey', 390.

80 Jane Carey, 'Engendering Scientific Pursuits: Australian Women and Science, 1880-1960', Limina: A Journal of Historical and Cultural Studies, 10 (2010): 20.

81 Ibid., 20-21.

82 Kraehenbuehl, 'Jessie Louisa Hussey', 394, 391; Maroske and Vaughan, 'Biographical Register', 94. 
continued to be compelling. ${ }^{83}$ As revealed in the Field Naturalists, the self-taught amateur botanist continued to impact through hard work, persistence and the understanding that duty to science would be its own reward. One of Hussey's obituaries in 1898 described her as 'An Earnest Scientific Worker', another dubbed her 'an ardent and devoted worker', demonstrating that, even at the time, her contribution was recognised as significant with 'worker' a noble epithet. ${ }^{84}$ While in some respects, Jessie's occupation as collector defied societal expectations, as with other female collectors it was entirely voluntary, unpaid and at the behest of Mueller. Field Naturalist accounts of 1896 explain that nearly all Hussey's collection had been determined by Mueller and highlight the significance of the 'valuable time' he gave to identifying her specimens. ${ }^{85}$

\section{Scientists}

The formally untrained Hussey could be said to have made an unpaid career of her scientific endeavours, yet the path of women with scientific degrees who joined the Field Naturalists was problematic. Liberal-minded spokespeople in South Australia saw higher education as vital for women's role in building colonial society and thus when Edith Dornwell, the first female science graduate in Australia, came from the University of Adelaide it was viewed as a proud testament to its progressive status. ${ }^{86} \mathrm{It}$ is into this context that we see some women with science degrees entering the Field Naturalists after finishing their degrees in the 1890s and early 1900s. A similar pattern emerged with the Victorian Naturalists, with the first science graduate joining in 1893 , and more following. ${ }^{87}$

Three women with science degrees have been identified in the Field Naturalists towards the end of the century, a reasonable number given only 11 had graduated in science by 1900 . While the cohort is admittedly small, their reaction to the organisation provides some interesting comments on women's position in the scientific arena at the time. One was 'E.F. [Edith Florence] Haycraft', who completed her Bachelor of Science in 1895 . Again, a family interest in science can be observed, with

83 Register, 17 March 1899, 7; Hooker, Irresistible Forces, 20.

84 Register, 20 March 1899, 3; Register 17 March 1899, 7.

85 Chronicle, 14 November 1896, 18.

86 Mackinnon, The New Woman, 15; Carey, 'No Place for a Woman?', 156.

87 Houghton, 'Women in the Field Naturalist Club of Victoria', 296. 
her father's lifelong hobby being the study of minerals and chemistry. ${ }^{88}$ The meeting in 1895 where Haycraft first appears suggests the gender hierarchy of the organisation, with the 'chief business' taking the form of questions by the general members and answers delivered by male authorities, 'all experts in their respective departments' ${ }^{89}$ It has been suggested that women in science societies took care that their behaviour did not transgress social boundaries, but it was into this milieu that Haycraft not only brought botanical specimens but assertively explained their function. ${ }^{90}$ In November 1895 she again took on an instructional role, exhibiting under the microscope some gold crystals, using the 'Haycraft' extraction method. ${ }^{91}$ Haycraft took advantage of opportunities, often showing botanical exhibits from her travels, was the first woman elected to the Committee, between 1895-97, and was the sole female to present a paper at the 1896 Learned Societies' conversazione. She appears to have been treated equally with her male counterparts; for example, when on the 1896 camp she was placed with male science specialists, and her degree noted: 'Botany will be represented by Miss E.F. Haycraft B.Sc'. The final reference to Haycraft came in 1900 when she delivered a paper on the properties of leaves. ${ }^{92}$ She was a forthright character, ready to offer her opinion, as evidenced by her numerous letters to newspapers. Earlier in the nineteenth century women often saw themselves as collectors or amateurs, as opposed to men who were 'scientists. ${ }^{93}$ However, by the century's end the conference of degrees saw a shift in perceptions. Haycraft frequently and proudly displayed her credentials, signing off as 'E.F. Haycraft B. Sc.'. ${ }^{94}$

The inclusion of one woman on the Committee was followed by more, with both S. L. Schourup and Wilhelmina Heynemann appearing alongside Haycraft in 1896. Heynemann had been teaching since 1890, at which time she was also listed as a member of the Field Naturalists, had passed her teaching exam in 1891, and went on to complete a science degree in 1896 in biology at the University of Adelaide, where she presumably

88 MacKinnon, The New Woman, 27; Register, 14 April 1897; Register, 20 April 1898; Observer, 5 May 1928, 21.

89 Observer, 13 April 1895, 13.

90 Kennedy, 'Science Culture', 62.

91 Evening Journal, 20 November 1895, 2; Advertiser, 7 March 1896, 6.

92 Register, 20 September 1895; Register, 9 November 1896; Chronicle, 21 November 1896; Advertiser, 24 September 1896, 3; Advertiser, 24 August 1900.

93 Maroske, 'Whole Great Continent', 18-19.

94 Register, 14 December 1920, 5. 
would have known Haycraft. She served on the committee again in 1897, but thereafter there is no mention of her in the organisation. ${ }^{95}$ Edith Collison also joined after finishing her science degree. Educated at the Advanced School for Girls, Collison then proceeded to a science degree where she attained consistently high grades in geology, maths and botany, won a government scholarship in her second year and finished her degree in geology in $1898 .{ }^{96}$ Collison appears to have only briefly attended the Field Naturalists, but is notable in that she travelled to Tasmania in 1902 with a number of other geologists on a trip organised by the AAAS. She reported back to the Field Naturalists, giving details about the mining centres, and the geology and vegetation of Tasmania. ${ }^{97}$

While scientific women were able to achieve a voice through their papers in the Field Naturalists, it is questionable as to whether the organisation advanced their ambitions. The lack of serious encouragement for females with scientific aspirations can be seen when a Boys Club was started to promote the study of natural history but there was no equivalent girls club, despite it being noted from within the organisation that an important educational function was being served but 'for one sex'. ${ }^{98}$ While both Collison and Haycraft read papers, neither woman joined the Royal Society, even though men with only a peripheral interest were elected Fellows. At times female members looked to new organisations, with Selway and Collison involved in the AAAS, an organisation that was 'deliberately egalitarian', allowing women to give papers and become associate members. ${ }^{99}$

For scientific women, it appears that men in the Field Naturalists had a head start, they were more qualified, more expert. Women found a place on the committee but did not, or could not, rise any further. Hooker has argued that women in science in the nineteenth century were 'popularisers, rather than theorists, illustrators rather than authorities', but the actions of female scientists in the Field Naturalists reveal a desire to move beyond their allocated roles and, indeed, to be both theorisers and authorities. ${ }^{100}$ Heynemann had been active in the Wattle Blossom

95 Register, 10 March 1890, 6; 'List of Members', 30 September 1890, Proceedings 1889-90, 39; Chronicle, 23 January 1892, 8; Express and Telegraph, 2 December 1896, 3; Advertiser, 24 September $1896,3$.

96 Register, 12 December 1890, 7; Advertiser, 6 December 1898, 7.

97 Register, 21 May 1902, 6.

98 Evening Journal, 12 August 1893, 6; Register, 4 November 1889, 5.

99 Hooker, Irresistible Forces, 65.

100 Ibid., 12. 
League since 1890. Somewhat ironically, she had established her scientific expertise in this organisation even before commencing her degree, with an 1891 talk on 'Animal and Vegetable Cells' illustrated through diagrams and microscopes. Nevertheless, she did not deliver a paper to the Field Naturalists, suggesting that she felt more comfortable in the League's all-female environment where she was the undisputed expert. By 1893 Heynemann was vice-president of the League and after leaving the Field Naturalists joined the Library Association of Australasia. ${ }^{101}$ Examination of the first generation of female science graduates in Victoria has found that they were often active in women's organisations and other community bodies, and this is also true of both Haycraft and Heynemann. ${ }^{102}$ Haycraft had an active public life and also directed her energies in other areas. By 1916 she was in the Theosophical Society giving a talk in which she theorised about the great cycles of nature. She then went on to participate in the women's movement and became secretary of South Australia's proportional representation organisation for over 10 years. ${ }^{103}$

Moreover, while women could study science, there were few employment opportunities or career pathways apart from teaching. While from within science there may have been acceptance of women's higher education, Edith Dornwell points to wider perceptions in society when she said that there was 'much prejudice in those days against the advancement of women, and against their entry into universities'. ${ }^{104}$ Moreover, the upper echelons remained blocked. Carey acknowledges that, although women were welcomed into universities, this was partly due to low numbers in science degrees and, even when women were appointed professionally to positions in the early twentieth century, their services were acquired at 'bargain rates'. ${ }^{105}$ Haycraft took up the teaching option, although in maths, not miology. When Heynemann died in 1907, aged 44, the inquest reported that she was single and working as a typist. Collison transitioned to a traditionally feminine sphere, opening a Rest and Convalescent Hospital at Mount Lofty named 'Karrawirra' with her sister. ${ }^{106}$

101 Evening Journal, 4 December 1891, 2; Chronicle, 18 February 1893; Evening Journal, 6 May 1893, 4; Register, 5 September 1900, 9.

102 Farley Kelly, 'Women Making Careers', in On the Edge of Discovery, ed. Kelly, 45.

103 Chronicle, 6 November 1926, 47; Register, 12 January 1916, 6; Advertiser, 12 November 1943, 6; News, 4 March 1944, 4.

104 MacKinnon, The New Woman, 32.

105 Carey, 'Engendering Scientific Pursuits', 18; Carey, 'No Place for a Woman', 161.

106 Evening Journal, 6 November 1920, 1; Express and Telegraph, 25 June 1907, 1; Mail, 30 September 1916, 7. 


\section{Conclusion}

The significance of the South Australian Field Naturalists in popularising interaction with the natural world was highlighted at its 25th anniversary, where it was noted that they had inculcated a love of nature in a large number of persons, and provided for many healthy outings and profitable evening meetings. ${ }^{107}$ The organisation provided informal and femalefriendly participation in science, but they also supplied healthy outdoor recreation. Activities included pastimes heavily contributed to by women such as illustrating, collecting, singing, afternoon tea, gossip evenings and exhibiting, highlighting that the original South Australian Field Naturalist organisation had markedly different characteristics to its current manifestation. While the available historical records provide few diaries or journals recording women's comments on their involvement, their actions are telling. Women often contributed collaboratively, at times in conjunction with family members. Changing ideas in the $1890 \mathrm{~s}$ were accompanied by greater female involvement and, by the end of the period examined, women at times outnumbered men on excursions and were increasingly active physically. Women hiked along with the men, they exhibited a variety of artefacts in numbers that typically equalled men's, and they pushed the organisation in new recreational directions.

The Field Naturalists meant very different things to the women involved in it. For some, such as Chrissie Selway and Lottie Benda, it was a significant aspect of their lives over a long period and an organisation they devoted considerable time to. Generally, the main women examined had some interesting commonalities. As expected, they were all middle class, but Selway, Rosa Fiveash and Jessie Hussey also all donated their collections and paintings to public institutions thus emphasising not only their duty to science and society, but the value they attributed to their work. ${ }^{108}$ An interesting commonality of many of the women examined, Selway, Benda, Hussey, Edith Collison, Fiveash, Edith Haycraft, and Wilhelmina Heynemann, was that they all remained single. ${ }^{109}$

107 Advertiser, 19 November 1908, 8.

108 News, 4 August 1937, 9; 'Hussey, Jessie Louisa (Louise) (1862-1899)', Australian National Herbarium, www.anbg.gov.au/biography/hussey-jessie.html; Australian Women's Mirror, January 10 1928, 20; Register, 19 November 1927, 5.

109 Express and Telegraph, 25 June 1907, 1; Chronicle, 25 March 1899; Register, 28 September 1920, 6. 
Collectors and illustrators linked to the Field Naturalists made a significant contribution to our understanding of the South Australian environment, with many young women also interested in Aboriginal culture, albeit from a colonising perspective. However, studies of female illustrators and collectors have rarely focused on their role in organisations. For those such as Selway, Hussey and Fiveash, their continued involvement suggests it was beneficial. As Moyal has noted when examining women in science during colonial times, 'only a rare kind of woman could make a conspicuous impact', and this is also the case here. ${ }^{110}$ For those in the Field Naturalists whose impact was acknowledged, particularly Fiveash and Hussey, it took a life devoted to scientific or illustrative endeavour.

Starting from the early applause at the announcement of the inclusion of women in the Field Naturalists in 1883, there were earnest attempts at promoting female participation. However, the few female scientists who joined the organisation left after a number of years: their voice appeared through their reading of papers, but they appeared to have had no further path in the Field Naturalists, or, indeed, in the scientific arena. Again, their actions are telling. It appears that these women were able to achieve greater leadership opportunities elsewhere, particularly in organisations run by women, such as Edith Haycraft, who was increasingly political and took up other causes. The Field Naturalists organisation was both enriched and limited by its origins with the Royal Society, with analysis of gender hierarchy showing a leadership structure difficult for women to penetrate. Moreover, at this transitional time, it was those who accorded with more traditional feminine stereotypes that were able to gain the respect from the wider society and the organisation because of their perceived selfless devotion to the cause of science. 
This text is taken from Lilith: A Feminist History Journal: Number 27, published 2021 by ANU Press, The Australian National University,

Canberra, Australia.

doi.org/10.22459/LFHJ.27.03 